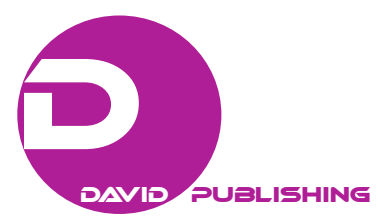

\title{
Fansubbing Humor: A Mainland China Case Study
}

\author{
CAI Xiu-xing \\ Xiamen University Tan Kah Kee College, Fujian, China
}

\begin{abstract}
Fansubbing, short for fan subtitling, is a new form of subtitling done by fans for fans voluntarily and collaboratively to distribute free fansubbed programs. Fansub is a virtual community where fansubbers communicate only through chatting rooms, forums, MSN or QQ. With the popularity of audiovisual programs on the Internet, fansubs become well-known for their voluntary fansubbed programs and interesting fansubbing. However, little is known about the operating of this virtual community and the strategies of fansubbing humor. Thus, this dissertation explores the modus operandi of fansubs in Mainland China, and discusses fansubbing strategies compared with that of mainstream subtitling, with particular emphasis on fansubbed humor in American TV series which are popular with Chinese audiences. Different from the mainstream subtitling which often domesticates the otherness in the foreign culture, fansubbing tends to rewrite and manipulate the translation in a more idiosyncratic and creative way. Fansubbers recreate the humor in an "abusive" way to explain the cultural difficulties. And their "abusive" manipulation of translation, especially in humor translation, which helps the audience to overcome the culture barriers, experience the cultural "otherness" while entertain the humor, has great potential to be adopted by other translators in dealing with translating cultural difficulties.
\end{abstract}

Keywords: fansubbing, humor translation, manipulation, Mainland China

\section{An Overview of Fansubbing in Mainland China}

The popularity of the Internet has brought great revolution to the production of subtitles in China ${ }^{1}$. Unlike the traditional subtitling which could only be done by subtitlers with the expensive subtitling programs, the free access to the subtitling software on the Internet enables people to create subtitles by themselves easily. The new subtitling practice is best seen in the dramatic increase of fansubbing.

Fansubbing is a new form of subtitling to provide the free distribution of audiovisual programs with subtitles done by fans over the Internet. Those fans work collaboratively in the virtually community, i.e., fansub, and communicate on the Internet through chatting rooms, forums, BBS (Bulletin Board System), MSN or QQ. They prefer to use the term "subbing" instead of "subtitling" to "emphasize the peculiar nature of this activity" (Diaz-Cintas, 2005, p. 16). The origin of fansubbing goes back to the 1980s with the creation of the first anime club in Japan and it became popular with the easy access to cheap computer software and free subbing equipment on the Internet in the mid-1990s (Diaz-Cintas \& Munoz-Sanchez, 2006, p. 37).

The development of fansubs in China had a lot to do with the popularity of BitTorrent ${ }^{2}$ forum between the year 2003 to 2004 (HU, 2009), which provided the largest downloading and uploading for the Chinese netizens. But it was not until the popularity of American TV series Prison Break in 2006 in China and the report on

CAI Xiu-xing, M.A., Foreign Language Teaching Department, Xiamen University Tan Kah Kee College.

1 "China" in this paper refers to Mainland China.

2 A peer-to-peer (P2P) communication system for downloading and uploading. 
fansubbers by The New York Times journalist Howard W. French (2006) that fansubs began to attract people's great attention and played a vital part in audiovisual programs on the internet.

On 9th August, 2006, French (2006) managed to interview two fansubbers from two different fansubs and published a report on their subbing work and reasons for subbing the US TV shows. It was the first time for the public to know the real life of fansubbers in China. Since then, more and more reports about Chinese fansubs have appeared in the newspapers, magazines, and even research papers in recent years.

According to the statistics by HU (2009, pp. 210-212), during May 1st to June 1st in 2009 on BT@CHINA, which was banned and closed by the government in November 2009, there were 84 fansubs, including 27 Japanese anime fansubs, 21 foreign film fansubs (20 for English films and 1 for Thailand film), 12 American TV series fansubs, 8 Korean TV series fansubs, 7 Japanese and Korean variety show fansubs, 6 Japanese TV series fansubs and 3 Thailand TV series fansubs. Besides the fansubs mentioned, there are more new fansubs in recent years with the popularity of MIT OpenCourseWare Projects, e.g., MyOOPS and OCourse which are responsible for fansubbing open courses in American top Universities like MIT, Yale, and Harvard.

Among the English-Chinese fansubs, the most well-known and influential fansubs now in China are FR, YDY, and YYeTs ${ }^{3}$. Though every fansub conveys the same idea of sharing free information, communicating and learning, each fansub has its own characteristics.

FR and YDY are famous for their fansubbing TV series. FR is claimed to be the paradise of U.S.TV series and has forum for discussion while YDY is designed for the communication for foreign TV series with BBS for discussion. They provide sections for different genres of TV series, like crime, science-fiction, comedy, reality show, and law etc. Different from FR and YDY which only have forum, BBS or Sina Weibo, YYeTs has its own professional website which provides a lot of valuable information: trendy information, resource introduction, subtitle downloading area, open course area, Sina Weibo, audiovisual programs downloading area, forum, recruitment section and even searching engine. Besides, YYeTs deals with various aspects: Japanese and European anime, Korean variety shows, films and TV series, reality shows, sitcoms, films, etc. And it is well-known for its bilingual subtitles and subbed open course from the beginning of 2010. Because of its great popularity and professionalization, the fansub YYeTs will be studied as a major case in this paper.

\section{The Modus Operandi of Fansubs}

Like other collaborative translations which have a professional team to work together, fansubs also have a team cooperating together to finish each episode. Generally speaking, a fansub consists of the raw provider, the translator, the timer, the typesetter, the editor and proof-reader as well as the encoder: The raw provider is responsible for "ripping" the raw audiovisual programs from the original source, typically DVD or TV, to the fansub's FTP (File Transfer Protocol) server computer; the translator is in charge of transferring the dialogue into the target language and sent it in the form of a text file to the timer; the timer enhances the script by synchronizing the translated dialogue with the audio file, saves the script as SSA (Sub Station Alpha) format and sends to the typesetter; the typesetter's task is to choose the fonts and colors for different types of screen text and signage; the editor and proof-reader is in charge of revising and polishing the translation if necessary to ensure the overall quality; and then the encoder will produce the final subtitled version using the raw

\footnotetext{
${ }^{3}$ FR is short for the fansub "Feng-Ruan" 風軟. YDY is short for the fansub "Yi-Dian-Yuan"伊甸園. YYeTs is short for the fansub "Ren-Ren Yings-Shi”人人影視. The following statistics and episodes related to the three fansubs are all from their bbs, forum and website. The English versions of the information from the websites are translated by the author.
} 
audiovisual program and finalized edited subtitles (Diaz-Cintas \& Munoz-Sanchez, 2006, pp. 40-43; Gonzalez, 2006, pp. 266-268).

However, during the process, one fansubber may be in charge of several jobs at the same time. According to the interview ${ }^{4}$ with Mr. L, a translator in the fansub YYeTs, the translator is not only responsible for the translation, sometimes, he/she also does the proof-reading and editing, and checks the spotting to make sure the synchronization of the timing and the dialogue list. Besides, as can be seen from the fansub credits shown during the opening song, there is no position for the typesetter and usually the editor's name also shows on the proof-reader's list because the encoder will do the typesetting and the editor will also do the proof-reading. In the fansub, everyone is versatile and ready to cooperate in an efficient way to advance the subbed programs ahead of other fansubs to attract more audience.

According to the report conducted by CHEN and LIU (2006), as well as the fansubbers' after-fansubbing experience on the forum, the fansubbing process could be summed up with the example of fansubbing the 13th episode in Prison Break Season 2.

After one episode is broadcasted in America around 8:00 pm EST, that is about 8:00 am Beijing time, different raw versions of AVI without subtitles could be downloaded from BT website at around 9:00 am. The most well-known foreign 0-day raw providing communities are LOL and XOR. They record the TV series, transfer to AVI format and then upload on the web on the same day. It normally takes half an hour for raw providers to download the AVI from foreign BT Web to fansubs' FTP in China. To save time, some fansubs will make use of Korea server to send the AVI to China, which will take only 10 minutes. Fansubs in China also have their overseas fansubbers to convert the ready-made English subtitles to texts with special equipment and software.

Around 9:30 am, when raw material and English subtitles are ready, the supervisor will ask the timer, the translators, the editor and encoder to download the episode from FTP. At about 10:00, the downloading is finished and the timer will first define the in and out time of each subtitle with the software of PopSub, Cysub, etc. While spotting the time, the timer will also delete the advertisements in the subtitles to avoid distracting. The work of the timer needs great patience because minor mistakes will spoil the whole episode. For a 45 minute episode, an experienced timer needs about two hours.

At about 12:00 am, subtitles with timing will be sent to the translator. If there are two translators, each translator will need to translate about 20 minutes conversation with 400 sentences within four hours. Usually, more translators will be added to help finish a popular episode in the shortest time, so that the fansubbed episode could be uploaded as quickly as possible to attract more audiences. When rendering the subtitles, the translator will also need to check the timing just in case. Besides, the translator must pay great attention to time and space constraints and make sure that there are not more than two lines on the screen and less than 16 Chinese characters in one line.

Then the proof-reader and editor will check the translation and the timing, and then do the editing if necessary. After proof-reading and editing, the supervisor will upload Chinese subtitles on the website www.shooter. $\mathrm{cn}^{5}$ for the audience to download first. After two hours, around 6:00 pm, the encoder will finish

\footnotetext{
${ }^{4}$ The interviews with Mr. L and Mr. S are summarized with the key points in the Appendix, and to protect the privacy of the two interviewees, Mr. L and Mr. S will be used instead of their real names. About the contents of the two interviews, please see the Appendixes.

5 The hottest subtitle uploading and downloading website in China.
} 
the final product with Chinese subtitles and upload to the website.

From the broadcasting of the episode at 8:00 pm EST to the final fansubbed product at 6:00 pm, the whole fansubbing process takes less than 10 hours.

\section{Fansubbing as Rewriting and Manipulation}

Since "all texts are written within and bound by certain constraints that writers or translators somehow must overcome" (Diaz-Cintas \& Remael, 2007, p. 145), subtitling, a kind of essential form adopted by translators in AVT, is no exception. And the constraints of subtitling could be even greater mainly because of the spatial-temporal limitations that may not apply to other form of translations. Besides, the linguistic loss of the source text in the rendering from oral speech to written text is another factor that constrains subtitling. Though these constraints are great challenges that the subtitler must face, they provide enough room for the subtitler to rewrite the source text to overcome the difficulties. They "adapt, manipulate the originals they work with to some extent, usually to make them fit in with the dominant, or one of the dominant ideological and poetological currents of their time" (Lefevere, 1992, p. 8).

Constrained by the technological limitations, norms and standards set by the subtitling company to satisfy the commercial interests, mainstream subtitlers "conform the original to the rules, regulations, idioms, and frame of reference of the target language and its culture" (Nornes, 2004, p. 449). However, this practice adopted by the mainstream subtitler to "smooth over its textual violence and domesticate all otherness while pretending to bring the audience to an experience of the foreign" (Nornes, 2004, p. 449) is considered to be "corrupt" (Nornes, 2004, p. 449). It will lead to "the acculturisation or domestication of the source text in line with dominant conventions and expectancies prevailing in the TC [Target Culture] and more often than not, to the translator's effacement or invisibility" (Gonzalez, 2006, p. 264).

Compared with domestic strategies adopted in the mainstream subtitling, fansubbers tend to rewrite and manipulate the translation in a more idiosyncratic and creative way, to produce "abusive" subtitles "quite by instinct" (Nornes, 2004, p. 466). Because fansubbers work voluntarily to share free distribution to the fans, they are not constrained by the mainstream subtitling company. They are free to choose the episodes they like to translate from the Internet and adopt any strategies they prefer to render the subtitles. Actually, fansubs have and create their own poetics. Their poetics involves the device of the Internet, genres of pop languages, motifs and prototypical characters of being original and creativity, as well as the concept of fansub as patron, producer, distributor, and viewer. Thus, fansubbers enjoy a lot of freedom to rewrite and manipulate the subtitles as they like, e.g., using pop cultural expressions, adding annotations, creating new expressions, adding comments, etc. Fansubbing is also seen as a kind of creation because it "emphasizes what translators put in, and not only what they take out" to bring "a more rewarding discussion" and "an appreciation of different perspectives and strategies" (Maher, 2011, p. 18). And this kind of manipulation and creation are best seen in subbed humor which concerns culture signs that "empowers the translator to be creative" and "emphasizes the necessity of considering the reader's need" (Leppihalme, 1997, p. 100).

\section{Fansubbing Humor}

\section{About Humor and Humor Translation}

When talking about humor, people will naturally think of words like "funny" and "laughter", yet though "humor" has been discussed for a long time since Kant, there is no consensus on the definition. The Oxford 
Companion to Medicine (2001) illustrates humor's original meaning that "humors in medieval times were four fluids supposedly secreted in the body and responsible for a person's character: these were blood, phlegm, choler and melancholy". The definition implies that humor is like fluid which has the characteristic of uncertainty and that every person has a certain sense of humor which may not be easily perceived; The Oxford Dictionary of Byzantium (1991) notes that "laughter was considered in antiquity as a virtue, a divine quality", connecting humor with its expression, i.e., laughter; The Oxford Companion to the Bible (1993) says that "humor starts with the perception of irony or some other inconsistency..." illustrating humor's connection with irony and incongruity; The Oxford Guide to the United States Government (2001) claims that "humor has always been a ready weapon for members of Congress but also one that has often been aimed against them. Debaters use humor to put down their opponents", implying humor's aggressive function. As Maher (2011, p. 7) points out: "humor is born of the peculiar cultural, historical and social experience of a group of people", humor is a term with complex culture-bound characteristics. In spite of its complexity, Koestler (1974, p. 739) formulates a more acceptable definition: "humor can be defined as a type of stimulation that tends to elicit the laughter reflex". This type of stimulation is the characteristic of humor which could be the "superiority" over others or "incongruity" that is out of people's expectation, with the purpose to stimulate the audience's laughter.

Humor is divided by Koestler into verbal humor and situational humor. Verbal humor consists of puns, jokes, anecdotes, comics and satires whereas situational humor involves parody, deformity and other non-verbal humor (Koestler, 1974, pp. 745-748). While most humor deals with verbal humor, humor in the audiovisual programs involves both verbal and situational humor, thus the audience may not have so many difficulties in understanding the humor in the audiovisual programs. However, when the audiovisual programs are translated into another culture, humor translation plays a vital part in the programs. If the translated humor does not have the same effect to elicit the laughter as the humor does in the source culture, people will be at a loss and even feel irritated when the subtitle disagrees with the situation, especially in the sitcom where there are canned laughter to indicate the humorous effects. Therefore, when translated improperly, humor with culture signs can "become cultural bumps" (Leppihalme, 1997, p. 4) which will not arouse the emotional dynamics to laughter and may even confuse the audience. Besides, humor translation in the audiovisual programs are especially difficult due to the constraints of time and space.

Concerning the difficulties in translating humor with complex culture signs or culture-specific terms as well as spatial-temporal restrictions, humor translation is considered to be impossible. However, it is because of the complexity of humor and difficulties in translating humor that the study of humor translation is of great value, for the so-called "impossibility" provides translators enough room to adopt various strategies. And this kind of freedom in adopting various translating strategies is best seen in the fansubbed humor in the American comedies and TV series.

According to Koestler (1989, p. 750), there are three criteria to judge humor: originality, emphasis and economy. Originality provides surprise cuts across our expectations, emphasis is reached by means of exaggeration and simplification while economy means implicit hints instead of explicit statements. These three criteria could also be applied to the fansubbed humor to assess the humorous effect achieved.

\section{Fansubbing Humor}

American sitcoms are rather popular in China now, not only because of people's curiosity about the American culture but also because of the humor and wit implied in the programs. Two of the most popular 
sitcoms will mainly be analyzed below: How I Met Your Mother and The Big Band Theory.

The Big Band Theory is about five friends: four science genius Leonard, Sheldon, Howard, Raj and one beautiful lady Penny. The four guys are geniuses in their field yet socially awkward whereas Penny has excellent social skills and good common sense. The incongruity and contrastive life style of the five friends strike a lot of funny stories and laughter. The sitcom premiered on CBS in 2007 and now is in its ninth season. It won the People's Choice Award for Favorite Comedy in $2010^{6}$.

How I Met Your Mother tells the social and romantic story of Ted Mosby and his friends Marshall, Robin, Lily, and Barney with the voice-over narration of Ted to his son and daughter about the events that lead to his meeting their mother. The sitcom premiered on CBS (Columbia Broadcasting System) in 2005 and has eight seasons. It has won five Emmy Awards, including a nomination for "Outstanding Comedy Series" in 2009. And it also won the People's Choice Awards 2012 for Best TV Network Comedy ${ }^{7}$.

The reason to choose the two sitcoms as my major case studies is not only because of their great popularity in and abroad but also because of the originality and creativity fansubbers exhibit in the fansubbed humor in the two sitcoms. Instead of using common strategies like equivalence and fidelity, fansubbers manipulate the translation: they rewrite and recreate, using pop-culture words and dialectal terms in the target culture to transfer the cultural expressions which may be hard for the audience to understand; they add annotations to explain cultural terms to help the audience better enjoy the programs; and they even add comments to share their opinions with the audience.

Rewriting and recreating. Rewriting and recreating by using pop cultural expressions are usually adopted by fansubbers. They rewrite the translation intentionally by using web languages popular among the young people to attract the audience. They also recreate some expressions from the pop songs to show their creativity. Those translated expressions contains implicit meanings yet very exaggerating, and the application of the expressions on the screen is quite out of the audience's expectation and thus emphasizes the humorous effect. The following examples show the fansubbers' rewriting and recreating in using pop cultural expressions.

Example 2: After breaking up with his girlfriend Amy, Sheldon buys several cats to accompany him. He gives cats several interesting names, one of which is Zazzles, meaning zazzy, a combine word of pizazz and snazzy. However, “Zazzles" is translated into “Xili ge" [犀利哥 elder brother Trendy (a begger in China who is snapped in the street for his trendy dress but now the name refers to somebody who is funny and fashionable)], which has nothing to do with "Zazzles", yet it is this sudden shift that gives the image a sharp incongruity. The fansubber uses this shift to provoke laughter to attract the audience's attention. They rewrite and manipulate the translation in an idiosyncratic way.

Example 3: "You're dying of jealousy" in the above is translated into the pop cultural expression "ni jiu xianmu jiduhen ba" [你就羡慕婉妒恨吧 you just keep jealous, be envious and hate it (a pop cultural expression to emphasize jealousy)] to exaggerate the feeling of the actor. Actually, the faithful and equivalent translation of the sentence will be very plain and fail to catch the eye of the audience, but the rewriting will give the audience new humorous experience.

\footnotetext{
6 "http://en.wikipedia.org/wiki/The_Big_Bang_Theory (accessed 5 January 2012)" is the online source for the introduction of The Big Bang Theory.

7 "http://en.wikipedia.org/wiki/How_I_Met_Your_Mother (accessed 8 January 2012)" is the online source for the introduction of How I Met Your Mother.
} 
Example 4: When Sheldon is having breakfast, he could not help thinking what happens in the morning and Leonard asks him to stop thinking about the trivial. And Sheldon answers: "If I could, I would, but I can't so, I shan't'. The answer is very rhythmic and his murmuring the sentence bings a lot of fun to us. Instead of translating faithfully, the fansubber translates into "Jiujie bushi wo xiangting, xiangting jiu nengting de" [糾結 不是我想停 想停就能停的 thinkng is not something I can stop if I want to stop], which is the re-creation of the lyric from the pop song Aiqing Maimai [愛情買賣 Business of Love]: Aiqing bushi ni xiangmai, xiangmai jiuneng mai [愛情不是你想買 想買就能買 Love is not something you can buy if you want to buy]. The translation is implicit yet creative to show the fansubber's originality to achieve the humorous effect.

Besides rewriting and recreating the pop cultural expressions, fansubbers also use dialectal terms like "ou di shen a" [偶滴神㮌 my God (dialectal term in northern China which pronounce "wo de" (my) into "ou di")] to interpret "for God's sake", "suisui nian" [碎碎念 to mumble (Minnan dialect)] for "grind about". Unlike the mainstream subtitlers who only use standard language and are not allowed to use the dialectal terms, fansubbers have the freedom to manipulate the translation. The kind of interpreting may not be accepted by everyone, especially those who do not speak the dialect, but this may create new poetics for the audience to accept.

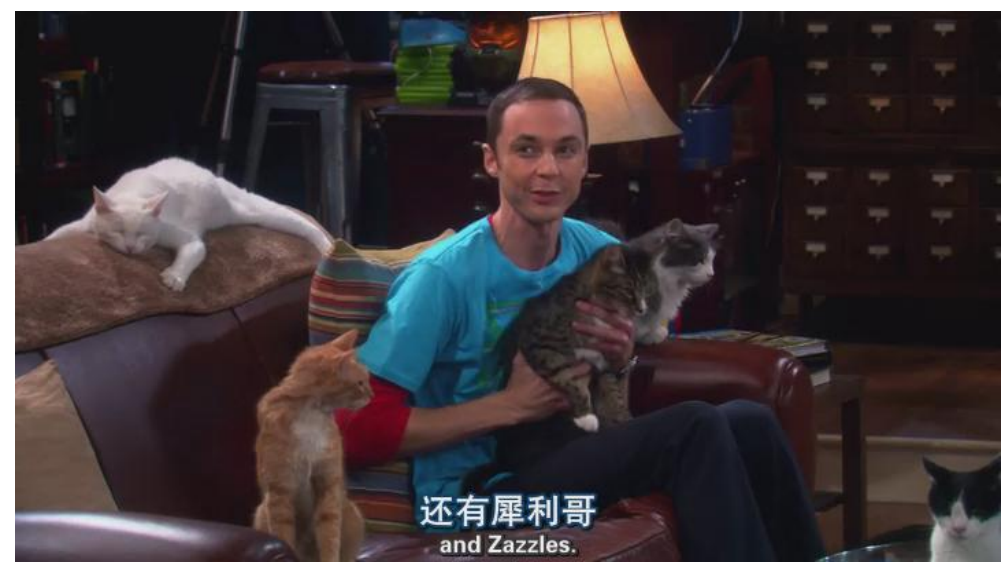

Example 2 (Cited from The.Big.Bang.Theory.S05E01, subbed by YYeTs) ${ }^{8}$.

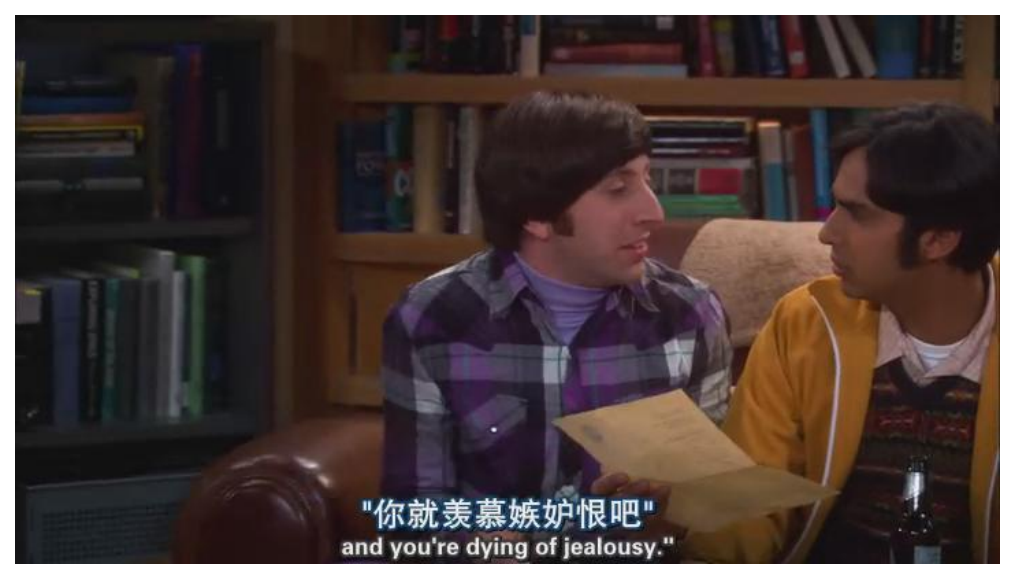

Example 3 (Cited from The.Big.Bang.Theory.S05E18, subbed by YYeTs) ${ }^{9}$.

\footnotetext{
8 “http://www.yyets.com/php/resource/11005 (accessed 4 January 2012)" is the online source for The Big Bang Theory S05E01. 9 "http://www.yyets.com/php/resource/11005 (accessed 18 February 2012)" is the online source for The Big Bang Theory S05E18.
} 


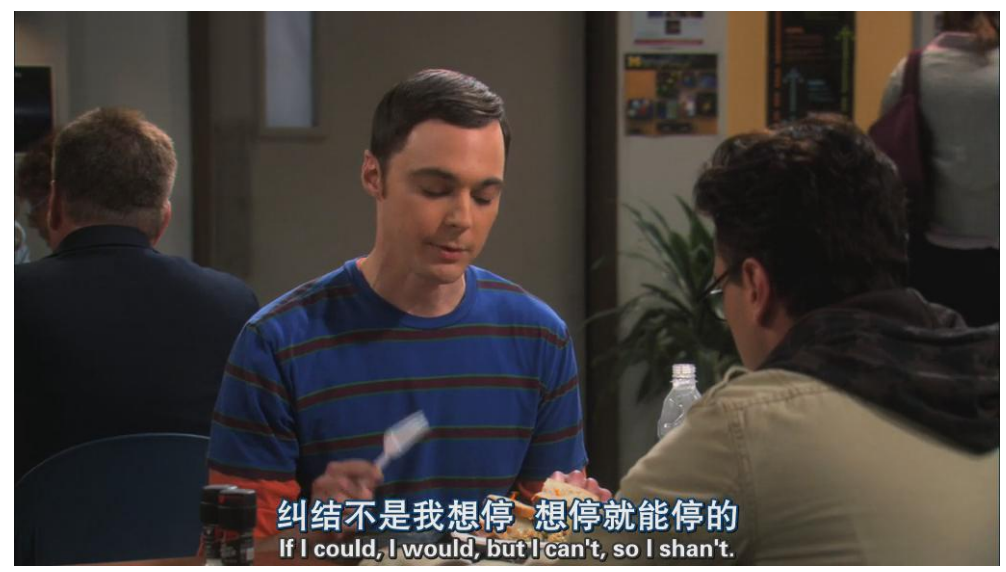

Example 4 (Cited from The.Big.Bang.Theory.S05E01, subbed by YYeTs).

Rewriting, recreating and annotating. Apart from using the pop cultural expressions and dialectal terms to translate humor, fansubbers are well-known for their annotations with rewriting and re-creation.

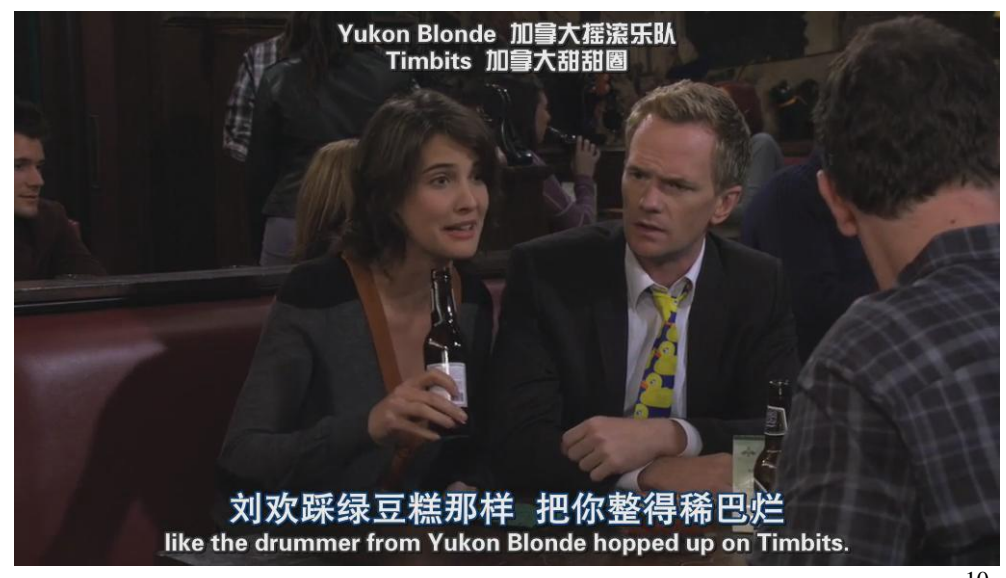

Example 5 (Cited from How I Met Your Mother S07E08, subbed by YYeTs) ${ }^{10}$.

\begin{abstract}
Barney: This is nice. What is this?
Waitress: Canadian whiskey.

Barney: I want scotch!

American scotch from Scotland!

Get that swill away from me!

Why are you doing this to me?

Robin: You have been ripping on Canada

since Justin Bieber was knee-high to a snow blower.

So now this Canuck's gonna beat on you

like the drummer from Yukon Blonde hopped up on Timbits.
\end{abstract}

In the above example, Robin orders a cup of Canadian whiskey instead of American scotch for Barney without telling him that it is Canadian whiskey. Barney enjoys the whiskey and asks the waitress the name of the whiskey. When he knows he is drinking Canadian whiskey he throws everything out because he is sick of Canadian. Thus Robin teases Barney, saying "You have been ripping on Canada since Justin Bieber was

10 "http://www.yyets.com/php/resource/26154 (accessed 8 January 2012)" is the online source for How I Met Your Mother S07E08. 
knee-high to a snow blower. So now this Canuck's gonna beat on you like the drummer from Yukon Blonde hopped up on Timbits". The fansubber translates "this Canuck's gonna beat on you like the drummer from Yukon Blonde hopped up on Timbits" into "xianzai zhege jianadaren yaoxiang Liu Huang cai lvdougao nayang ba ni zhengde xibalan” [現在這個加拿大人要像劉歡踩綠豆糕那樣 把你整得稀巴爛 now this Canadian is going to beat on you like Liu Huang stamps the green bean cake]. Yukon Blonde is interpreted into "Liu Huang", a well-known singer in China who is fat and stout. "Timbits" is rendered into "green bean cake", a sweet and tender dessert in China. Though the fansubber adds the annotation on the top of the screen: "Yukon Blonde is a Canadian rock band" and "Timbits are Canadian donuts", the audience may not find the humor here if it is translated literally due to the cultural difference. However, the rewriting and re-creating of the humor here provides a funny picture of big and stout Liu Huang stamping a tiny and soft cake. The superiority of making fun of the celebrity and incongruity of the image in the translated humor are successful to elicit the audience's laughter and thus achieve the humorous effect. Different from the mainstream subtitling which simply domesticates the cultural otherness, the fansubber explains the cultural differences with annotations to let the audience experience the cultural otherness.

Subbing and creating puns. Among various forms of verbal humor, puns enjoy a higher prestige because "puns are an exemplary product of language or mind" and "the foundation of letters" (Culler, 1988, p. 4) which can "produce humor, force the reader/listener into greater attention, add persuasive force to the statement, deceive our socially conditioned reflex against sexual and other taboo themes, and so forth" (Delabastita, 1996, pp. 129-130). Puns are rather difficult to translate, though puns in the audiovisual humor can be compensated by "combining the verbal and audiovisual components creatively" (Yau, 2010, p. 113). Usually, the subtitler will domesticate the pun or shun the pun by translating literally. However, the fansubber will try to keep the "otherness" of the culture while explaining the culture barrier by adding annotations up on the screen. The following example shows how the fansubber manages pun subbing.

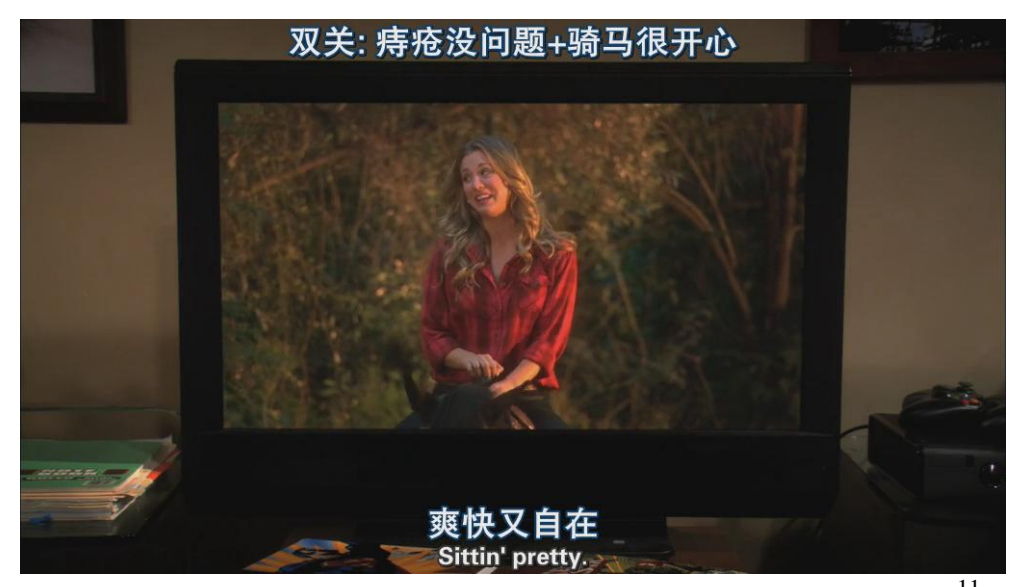

Example 6 (cited from The.Big.Bang.Theory.S05E01, subbed by YYeTs) ${ }^{11}$

Mom: Ready to ride?

Penny: I don't think so, Mom.

Not today.

Mom: Oh, sweetie.

Hemorrhoids acting up again?

11 "http://www.yyets.com/php/resource/11005 (accessed 4 January 2012)" is the online source for The Big Bang Theory S05E01. 


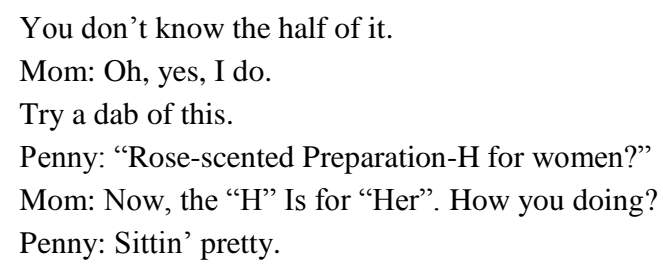

Penny finally gets a chance to become an "actress" on TV though she is only endorsing an ointment for hemorrhoids in the advertisement. She is very happy and is sharing her advertising with her friends. The advertising is set in the horse ranch. Mom asks Penny whether she is ready to ride. Penny could not because of the pain of hemorrhoids. Thus, Mom takes out an ointment and asks her to try a dab of this. The name of the ointment is "Rose-scented Preparation-H for women". The fansubber translates " $\mathrm{H}$ " into "White House" which is abusive and may confuse the audience because there is no "White House" in the source language. However, it is the metaphor of comparing "anus" to "White House" in the translation that creates a new pun in the target culture to achieve humorous effect. This created pun also well connects to the next translation: "the ' $\mathrm{H}$ ' is for “Her” is rendered into “xianzai baigong de damen shi zhuanweini erkai” [現在白宮的大門是專為你而開 now the White House is especially open for you]. When Mom asks Penny how she is feeling after using the ointment. Penny says "Sittin' Pretty" to imply the effectiveness of the ointment and her joyous feeling of being able to ride again. The fansubber translates the pun into "shuangkuai you zizai" [驱快又自在 refreshing and comfortable] and adds the annotation “shuangguan: zichuang meiwenti+qima henkaixin” [雙關: 㽷瘡没閣題+ 騎馬很開心 pun: no more hemorrhoids and riding is happy]. The annotation is quite helpful for the audience to appreciate the humor in the limited time when watching the audiovisual programs.

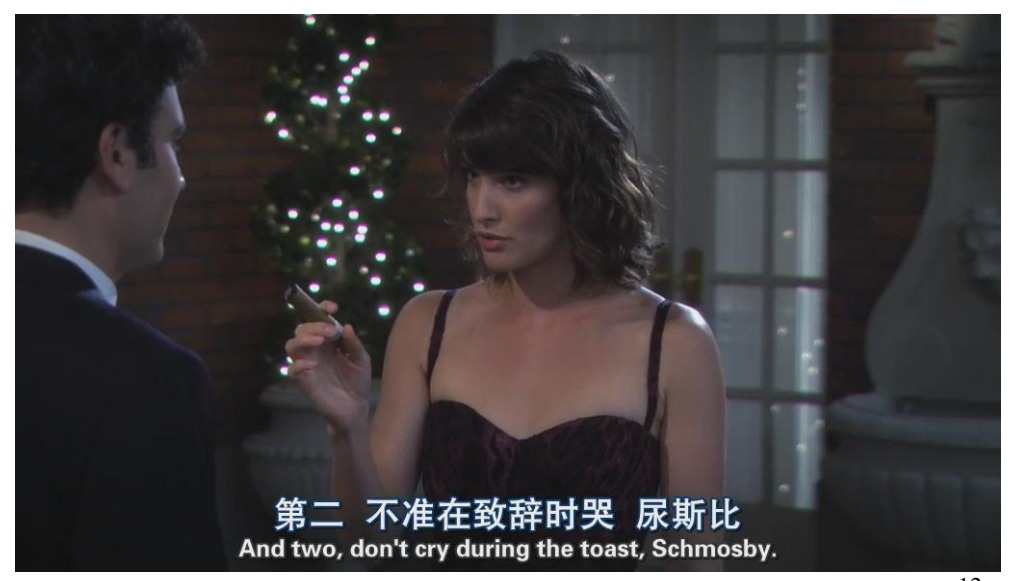

Example 7 (cited from How I Met Your Mother. E0701, subbed by YYeTs) ${ }^{12}$.

In this episode, Ted is going to give a toast at his friend's wedding. But since every time he gives a toast he cries and spoils the wedding, he is asked not to cry during the toast. His friend jokes at him and calls him “Schmosby" which is translated into "niao sibi" [尿斯比 peeing Mosbius (Ted's surname is Mosbius)]. Because Teb likes to cry and the sound of his crying sounds like peeing "sch", he is mocked by his friend by combining the sound of peeing "sch" with his surname "Mosbuis". The puns and humor are grasped by the fansubber implicitly and rendered in a creative and "abusive" way to elicit the laughter from the audience.

12 "http://www.yyets.com/php/resource/26154 (accessed 8 January 2012)" is the online source for How I Met Your Mother S07E01. 
Creating humor through commenting. Humor consists verbal humor and situational humor. When fansubbers translate the humor, they do not only translate the verbal humor, but also comment to render the "situational" humor to create another humor. They give comments on the funny things to interpret the "situational" humor and share their feelings with the audience. Adding comments is a very "abusive" way to manipulate the translation. However, fansubbers like to do so to show their identity and features distinctive from the mainstream subtitlers. In example 7, the fansubber adds comments "Bani neixin dubai ‘haoba...wodong” [巴尼内心獨白“好吧...我慬” Barney’s inner voice 'OK..I know'] to describe Barney’s reluctance to wear like a Canadian to attend a party at the request of Robin; in Example 8, the fansubber comments "xiaosile" [laugh to death] to express his/her feeling at hearing the funny Chinese from Howard; in Example 9, the fansubber comments on the embarrassed situation by adding several Chinese character "jiong" [圆 embarrassing (a new pop net-word used by young people to describe something embarrassing)]. Actually, these lines are not translated from the dialogue list. The fansubbers add the comments themselves. The strategy of adding comments by the fansubber is quite out of the audience's expectation and achieve the humorous effect to a certain extent.

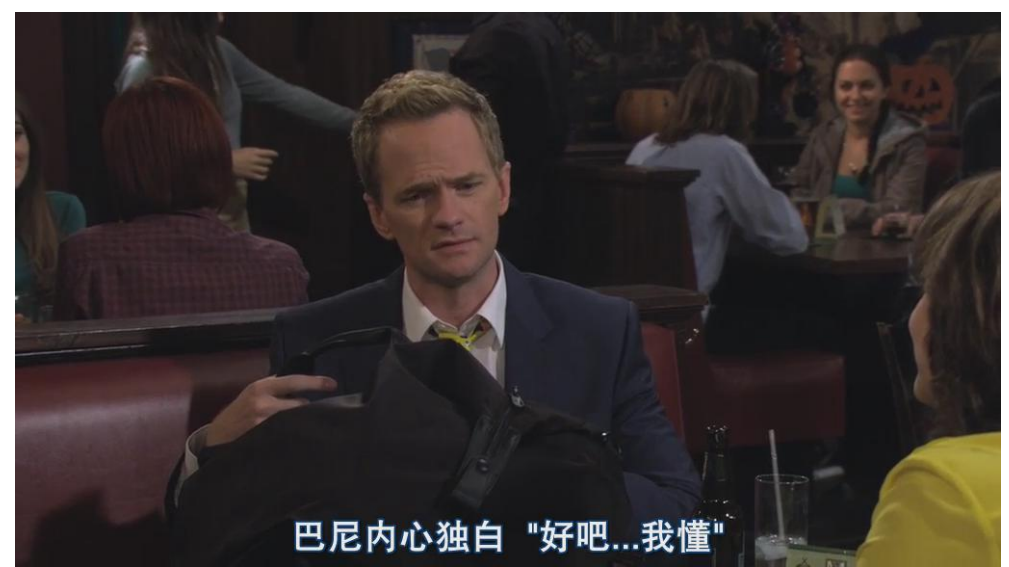

Example 8 (cited from How I Met Your Mother S07E08, subbed by YYeTs) ${ }^{13}$.

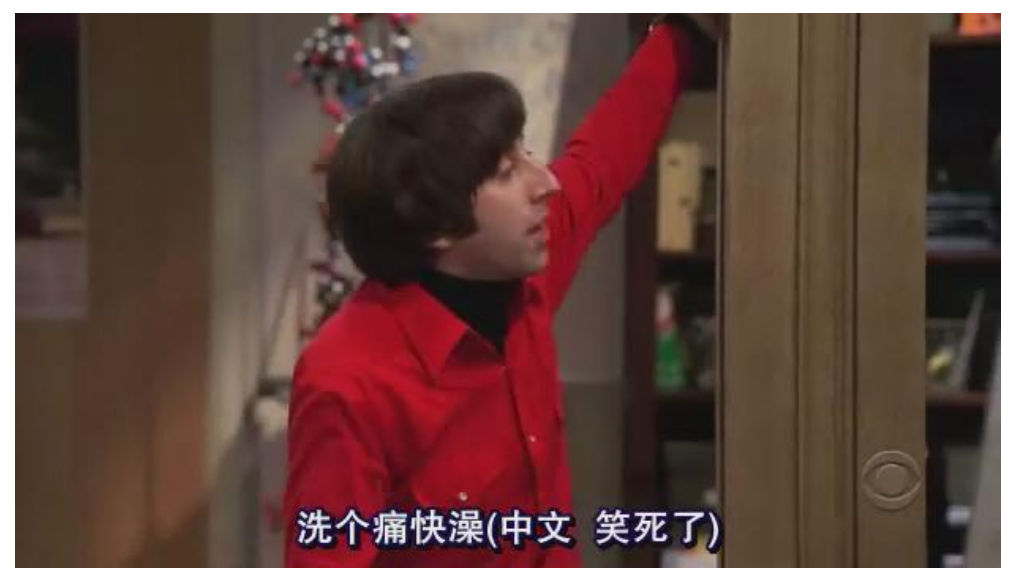

Example 9 (cited from The.Big.Bang.Theory.S01E01, subbed by YYeTs) ${ }^{14}$.

\footnotetext{
13 "http://www.yyets.com/php/resource/26154 (accessed 8 January 2012)" is the online source for How I Met Your Mother S07E08.

14 "http://www.yyets.com/php/subtitle/19301 (accessed 15 January 2012)" is the online source for The.Big.Bang.Theory.S01E01.
} 


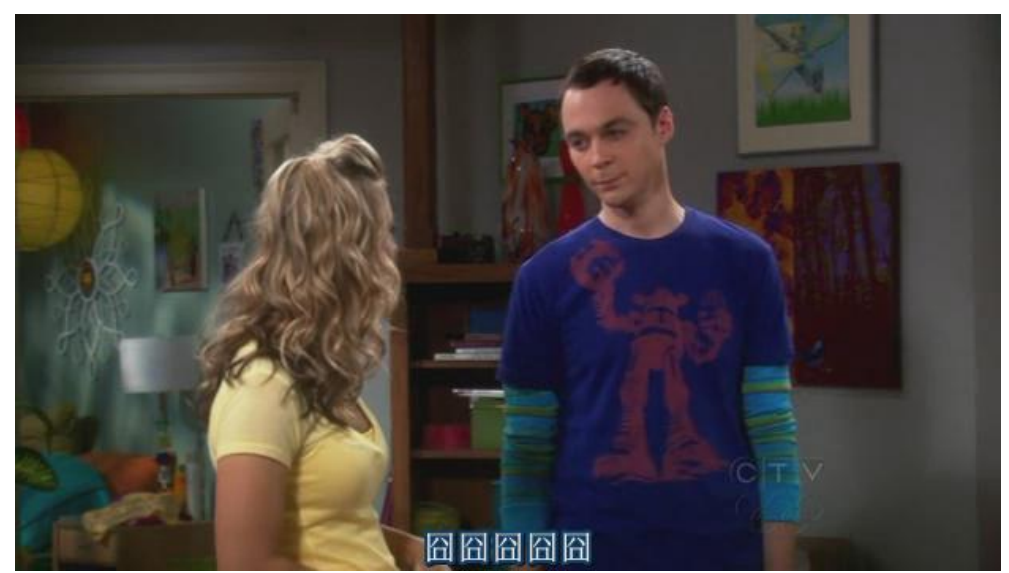

Example 10 (cited from The.Big.Bang.Theory.S02E18, subbed by YYeTs) ${ }^{15}$.

\section{Mainstream Subtitling and Fansubbing}

\section{The Characteristics of Mainstream Subtitling}

The development of the digital technology brings the emergence of the subtitling and makes it an important practice in the audiovisual translation. While benefiting from the technology to make the subtitling work easier, the mainstream subtitler also confronts constraints that demonstrate the basic characteristics of subtitling. The main constraints the subtitler faces are summarized by Hatim and Mason (1997) as:

(a) the loss of the features of speech, like dialect and intonation, in the target text, because of the shift in mode from speech to writing; (b) technical factors which control the conveying of the medium or the channel, i.e., spatial-temporal restriction which generally allows up to 33, or in some cases 40 keyboard spaces per line and no more than two lines on screen, and a minimum of two and a maximum of seven seconds for titles to remain on screen; (c) the reduction of the source text as a consequence of the spatial-temporal constraint which makes the translator reassess coherence during translating to maximize the retrievability of intended meaning from a more concise target language version; (d) the requirement of matching the visual image with the subtitled text which may at times create another constraint because the inconsistence of the text and visual image will ruin the whole program. (pp. 78-79)

Besides the four main constraints, other factors, like the choice of the source program, releasing of the subtitled program, releasing of the subtitled program, strategies that subtitlers adopt, etc. also account for the characteristics of mainstream subtitling.

Since mainstream subtitling is institutionally carried out by the subtitling company who works for the film agency or film company, the choice of the source audiovisual programs will be constrained by the agency or the film company. Take the mainstream subtitling in China for example, China Film Distribution Company, which is in charge of China's film import and distribution, sets some restrictions (QIAN, 2009) and has a strict censorship in the importing of the source program. Meanwhile, the distributing of the subtitled program will also be under strict censor.

In terms of the mainstream subtitlers, they are usually freelancers who work only part-time for subtitling company or film company, yet they are professionals who are usually specialized in subtitling. Since they are paid by the company, they are also constrained by conventions and norms. When the subtitlers get the dialogue

15 "http://http://www.yyets.com/php/subtitle/14579 (accessed 16 January 2012)" is the online source for The.Big.Bang.Theory.S02E18. 
list, they will also receive extra information and explanatory notes attached to the list which they need to be aware of. However, usually, the translators will not get the film copy with the dialogue list in case of illegal piracy. Thus, they cannot contextualize the dialogue as good as those who translate after watching the audiovisual program. And it is also another reason for the mainstream subtitler to take more time to finish the translation.

According to the interview with Mr. S, who has been a mainstream subtitler and head editor in a subtitling company for four years, the time for the subtitler for translating a 90-minute film is normally more than three days. Meanwhile, the strategies the subtitler adopts are also constrained by the conventions set by the company. The subtitler is required to translate faithfully and equivalently, using standard language with colloquial and daily expressions. To satisfy the commercial interest, domestication is adopted to attract more audience because it could be easily understood. Besides, the subtitler has no freedom in adding annotations, comments or using dialects in the subtitles. Thus, when encountering cultural barriers or puns which are difficult to translate, the subtitler just translates literally or use another example to domesticate the otherness. In addition, the status of mainstream subtitlers is rather low. Though they play a vital part in the whole subtitling process, no credits are showed on the screen for the subtitlers.

\section{The Characteristics of Fansubbing}

Fansubbing, a new form of subtitling done by fans for fans, was born in the 1980s "to provide fellow fans worldwide with the fullest and most authentic experience of anime action and the Japanese culture with embeds it" (Gonzalez, 2006, p. 260). Though the history of fansubbing is less than three decades, it has expanded with the widespread use of the internet and the free accessibility of subtitling programs on the internet. As a form of subtitling, fansubbing shares several characteristics with mainstream subtitling, like language transfer from speech to the written text, spatial-temporal restrictions, loss of the source text and coherence between the image and the subtitled text, etc.

However, some distinctive features of fansubbing distinguishes it from the mainstream subtitling. The main differences are summarized as follows:

(1) use of different fonts through the same program;

(2) use of colors to identify different actors;

(3) use of subtitles of more than two lines (up to four lines);

(4) use of notes at the top of the screen;

(5) use of glosses in the body of the subtitles;

(6) the position of subtitles varies on the screen;

(7) karaoke subtitling for opening and ending songs;

(8) adding of information regarding fansubbers;

(9) translation of opening and closing credits (Diaz-Cintas \& Munoz-Sanchez, 2006, p. 47).

Besides the above nine main features, other differences also account for their distinctive characteristics.

First is the freedom for the fansub to choose the source text they like from the internet and upload the subtitled programs on the internet. They are not constrained by the conventions and norms set in the mainstream subtitling since they are amateurs and work voluntarily. They themselves are "patrons, producers, distributors and viewers of the subtitled product" (Gonzalez, 2006, p. 268), thus they do not need to please anybody for their downloading of the source and the distribution of the subtitled programs. 
Second, unlike mainstream subtitlers who are professional freelancers in subtitling, fansubbers are amateur translators from all walks of life. They could be students, housewives etc. These amateur translators have many things in common: They all have much time sitting in front of the computer to do the translation and they enjoy a higher education background. Some of them are overseas students, and some even have achieved a very good score in taking different kind of English exams, like CET, TOELF or IELTS, and others even are good at translating many professional terms with their solid knowledge in the relative fields. The fansubbing of American TV series House M.D. and Grey's Anatomy by the fansub FR earned great praise from fans because of the translators' professional translation with their strengths in medical field. Besides, they devote themselves to the work out of their love for their favorite audiovisual programs rather than commercial benefits. And this kind of passion and being viewers themselves enable them to have a better understanding of the programs culturally, thus providing translations with "cultural idiosyncrasies of the original in the target text" (Diaz-Cintas, 2006, p. 46) to the special audience who share the same interest with them.

Another interesting characteristic is that fansubbers are not working invisibly like mainstream subtitlers. Fansub credits are shown during the open song of the subbed audiovisual programs. When people watch the audiovisual, they know immediately which fansub is doing the fansubbing and which fansubber is responsible for the translation, editing, timing, and encoding. Take the fansub YYeTs for example (see Example 1), the credits of the fansub and the fansubbers are shown at the open song. The credit of the fansub shows that "the subbing is done by YYeTs; for more original subbed version of American TV series, please visit our website www.YYeTs.com". And the credits of the fansubbers show that "translators: MADD, Tina, Haiyinlixi, Xiao Manyao; encoder: Gufan; Timer: YY; proof-reader: YY, MADD; editor: YY". This kind of credits is one of the encouragements for fansubbers to do the voluntary work to provide free distribution of subbed programs to the audience.

In addition, because of their voluntary work and intimate relationship with the fan audience who share the same interests, fans do not take a critical view to assess fansubbing. On the contrary, fans admire and appreciate the fansubbing. They even appreciate fansubbers' bold rewriting, adaptation or comments in the subtitles and will go to the forum to discuss the interesting translation with peer fans. And if there are any errors or mistakes, they will not be too critical, instead, they will kindly give suggestions in the forum.

However, since fansubbers enjoy a lot of freedom and no regulations really work on them, they may be leaving the fansub at any time though there is a requirement for the fansubber to work for more than three months after joining the fansub. And this kind of freedom will cause a lot of trouble for the fansub who is in the process of subbing a popular episode. They may lose a large quantity of fans if other fansubs are ahead of them to release the episode. Another problem will be that if the amateur fansubber has something more important or emergent to do during the process of translating, especially the fansubber who is an expert and in charge of specific programs, the fansubbing will come to a halt until the fansubber returns. One more disadvantage of fansubbing is the legal issue which involves the copyright of releasing the subbed audiovisual programs. To avoid legal disputes, fansubs will always write on the screen at the beginning of the episode that "the audiovisual program is only for share and communication with no commercial use, please delete it after watching within twenty-four hours". Even so, they risk breaching legal copyright. 

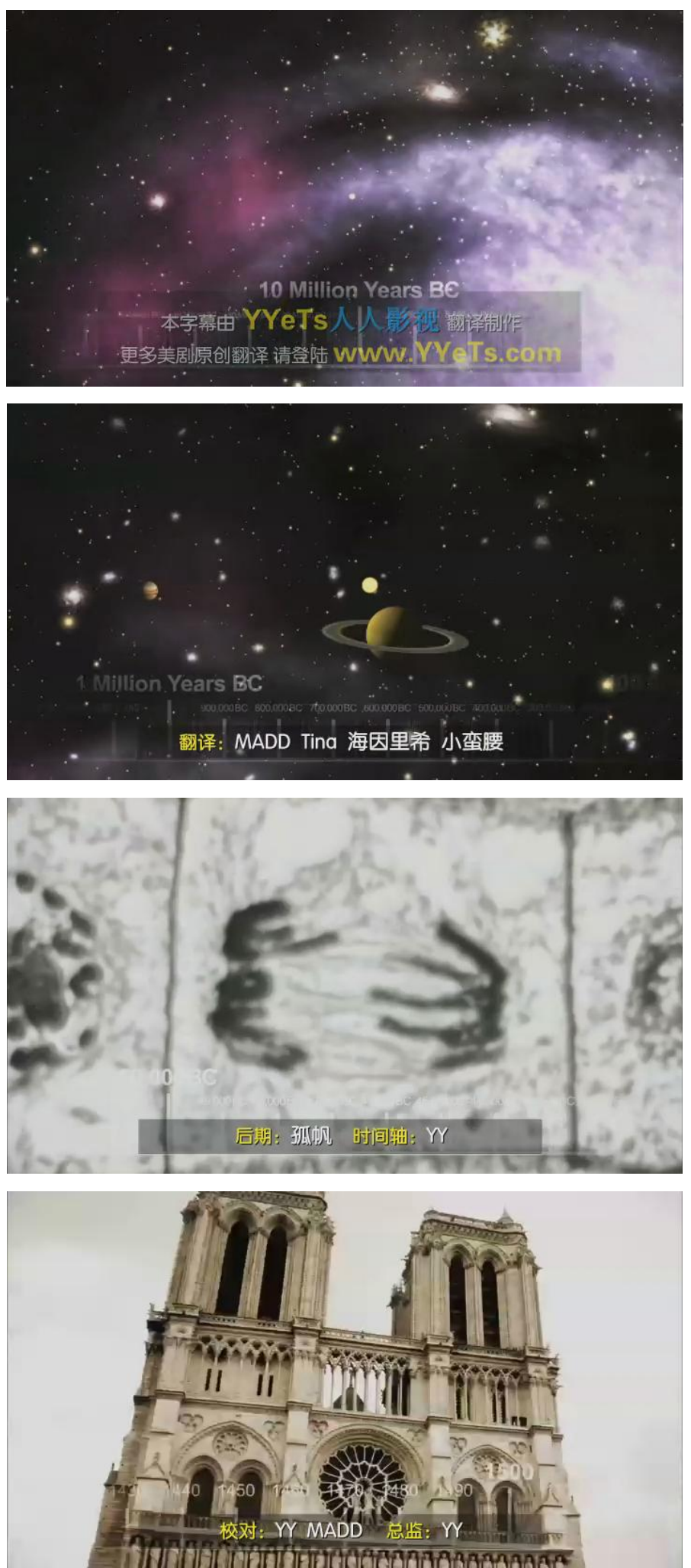

Example 1 (Fansub credits of YYeTs, cited from The Big Bang Theory. S05E02, subbed by YYeTs) ${ }^{16}$.

$\overline{16}$ "http://www.yyets.com/php/resource/11005 (accessed 3 January 2012)" is the online source for The Big Bang Theory S05E02. 


\section{Conclusion and Implication}

Fansubbing is a new phenomenon with the widespread use of the Internet and the free accessibility of the subtitling program. It is done by "fans for fans" in the virtual community where teamwork and cooperation are essential to produce final subbed products.

Fansubs expand quickly in China. From the year fansubs were known to the public in 2006, now, there are more than 90 fansubs to provide different versions of subtitles for different programs. They have their own forums, BBS, Weibo, and websites. Among all the fansubs, YYeTs stands out recently because of the profession in the design of the website and its large membership. Fansubs' subbing process is rather efficient, which normally takes within the same day to upload the subbed product of a newly broadcast episode. The time of one subbing episode is even reduced to eight hours from the source "ripping" to the uploading of the subtitles. Thus, fansubbing is becoming more and more popular because of their high efficiency.

As a new form of subtitling, fansubbing shares many characteristics with subtitling, like language transfer from speech to the written text, spatial-temporal restrictions, reduction of the source text at rendering, coherence between the image and the subtitles, etc. However, unlike the mainstream subtitling which is constrained by conventions and norms set by the subtitling or distributing company, fansubbing enjoys enough freedom to choose the source, sub the text, distribute the final product, etc. Actually, the fansub is the patron, producer, distributor, and viewer at the same time. Thus, fansubbing is not manipulated by other people. Instead, fansubbing is manipulated by the fansubs themselves, in a much more daring way which is "far less dogmatic and more creative and individualistic" (Diaz-Cintas, 2006, p. 51). The daring subbing is demonstrated not only in the creative form of fonts and colors, but also in the idiosyncratic strategies adopted by the fansubber.

Instead of using common strategies of equivalence and fidelity adopted by the mainstream subtitlers, fansubbers manipulate the translation: they rewrite and recreate, using pop-culture words and dialectal terms in the target culture to transfer the cultural terms which are hard for the audience to understand; they add annotations to explain cultural barriers to enable the audience to experience cultural "otherness" rather than domestic strategy often adopted by mainstream subtitlers; and they are even free to add comments to share their opinions with the audience. And these bold strategies are best demonstrated in the translating of humor because humor contains cultural signs that are thought to be difficult to translation.

Though the fansubbed translations, especially fansubbed humor, arouses a lot of controversies because of fansubbers' "abusive" way in manipulating the translations, fansubbers are respected and appreciated for their voluntary work and their creativity. And their "abusive" manipulation of translation, especially in humor translation, which helps the audience to overcome the culture barriers, experience the cultural "otherness" while entertaining the humor, have great potential to be adopted by other translators in dealing with translating cultural difficulties.

\section{References}

CHEN, S., \& LIU, Y. (2006). The popularity of prison break in China (“越狱”的中国隐秘流行). Retrieved 9 January, 2012, from http://lifeweek.com.cn/2006-12-21/0000417226.shtml

Culler, J. (1988). The call of the phoneme: Introduction. In J. Culler (Ed.), On Puns: The foundation of letters (pp. 1-16). Oxford: Basil Blackwell.

Delabastita, D. (1996). Wordplay and translation. Manchester/U.K.: St. Jerome Pub. 
Diaz-Cintas, J. (2005) Back to the future in subtitling. Proceedings from MuTru 2005-Challenges of Multidimensional Translation. Saarbrucken, Germany.

Diaz-Cintas, J., \& Munoz-Sanchez, P. (2006). Fansubs: Audiovisual translation in an amateur environment. The Journal of Specialised Translation, 6, 37-52.

Diaz-Cintas, J., \& Remael, A. (2007). Audiovisual translation: Subtitling. Manchester/UK; Kinderhook/NY: St. Jerome Pub.

Fengruan (風軟). (2012). Homepage (首頁). Retrieved 5 January, 2012, from http://www.1000fr.net

Gonzalez, L. P. (2006). Fansubbing anime: Insights into the "butterfly effect" of globalization on audiovisual translation. Perspectives: Studies in Translatology, 14(4), 260-277.

Hatim, B., \& Mason, I. (1997). The translator as communicator. London/New York: Routledge.

Howard, W. F. (2006). Chinese Tech Buffs Slake Thirst for U.S. TV shows. Retrieved 27 January, 2012, from http://www.nytimes.com/2006/08/09/world/asia/09china.html

HU, Q. Z. (2009). Working ethics of Chinese fansubbers and neo-liberalism (中国字幕组与新自由主义工作伦理). Journalism Studies (新闻学研究), 101, 177-214.

Koestler, A. (1989). Humor and wit. Encyclopaedia Britannica, 20, 739-745.

Lefevere, A. (1992). Translation, rewriting and the manipulation of literary fame. London/New York: Routledge.

Leppihalme, R. (1997). Culture bumps: An empirical approach to the translation of allusions. Clevedon/Philadelphia: Multilingual Matters.

Maher, B. (2011). Recreation and style: Translating humorous literature in Italian and English. Amsterdam, The Netherlands/Philadelphia, PA: John Benjamins Pub.

Nornes, A. M. (2004). For an abusive subtitling. In L. Vernuti (Ed.), The translation studies reader (pp. 447-469). London/New York: Routledge.

QIAN, S. C. (2009). Screen tranlation in Mainland China. In G. C. F. Fong, \& K. K. L. Au (Eds.), Dubbing and subtitling in a world context (pp. 13-22). Hong Kong: The Chinese University of Hong Kong.

Renrenyingshi (人人影視). (2012). Homepage (首頁). Retrieved 5 January, 2012, from http://yyets.com

The Oxford Companion to Medicine. (2001). Humors. Retrieved 27 January, 2012, from http://0-www.oxfordreference.com.hkbulib.hkbu.edu.hk/views/ENTRY.html?subview=Main\&entry=t185.e244

The Oxford Companion to the Bible. (1993). Irony and humor. Retrieved 27 January, 2012, from http://0-www.oxfordreference.com.hkbulib.hkbu.edu.hk/views/ENTRY.html?subview=Main\&entry=t120.e0351

The Oxford Dictionary of Byzantium. (1991). Humor. Retrieved 27 January, 2012, from http://0-www.oxfordreference.com.hkbulib.hkbu.edu.hk/views/ENTRY.html?subview=Main\&entry=t174.e2368

The Oxford Guide to the United States Government. (2001). Humor, Congressional. Retrieved 27 January, 2012, from http://0-www.oxfordreference.com.hkbulib.hkbu.edu.hk/views/ENTRY.html?subview=Main\&entry=t89.e423

YAU, W. P. (2010). Translating audiovisual humor: A Hong Kong case study. In D. Chiaro (Ed.), Translation, humour and the media (pp. 108-120). London:Continuum.

Yidianyuan (伊甸園). (2012). Homepage (首頁). Retrieved 5 January, 2012, from http://bbs.sfileydy.com

\section{Appendix A}

Item one: Interview note with Mr. S

Place: Student Canteen in City University of Hong Kong

Date: Jan. 10, 2012.

Time: 17:30-18:30

When did you become a subtitler?

(1) I joined in IVL (Intercontinental Video Limited) in Hong Kong 10 years ago and worked as a subtitler and head editor for four years.

(2) How many people were there in the subtitling department?

My department had eight in total. There were one head editor in charge of the whole process, five full time translators in charge of the translation and two typers to do the timing and editing. 
(3) What strategies did the translator adopt during the translating?

Normally, the translator translated in a faithful and equivalent way. We used colloquial and daily expressions to make the translation clear and easy to all the audience. And because of the time and space restrictions, we avoided wordy expressions.

(4) Will you use slang words or dialect in your translation?

No, we used standard language because it was accepted by everyone. The slang terms and dialects are only for the local people if the film or programs are to be broadcast there. But even so, it is not often adopted because it will only attract a small number of audience.

(5) How do you translate subtitles with culture signs, like humor?

We translated very literally or we domesticated the humor using a similar joke in the target culture. Actually, domestication was often adopted because of it could be easily understood by our audience.

(6) Did you add annotations or comments in the translation?

We were not allowed to add any annotations and comments. We were not free to do that. All we had to do was only to translate what was in the dialogue list.

(7) Do the subtitler have the credits on the screen?

No. The subtitler actually is not considered to be important for the film company. They only need the "fluent" version of the dialogue list from the subtitler and do not expect to thank them.

\section{Appendix B}

Item: Interview note with $\mathrm{Mr}$. L

Place: Student Canteen in Hong Kong Baptist University

Date: Jan. 12, 2012.

Time: 14:30-15:30

(1) When did you become a fansubber?

I became a fansubber three years ago when I was still in the university. I joined YYeTs and was responsible for translating the subtitles for House. M.D. at that time.

(2) What are the most influential fansubs in China now?

YYeTs is one of them, of course. A lot of audience download YYeTs's subbed programs because it is very good and provide different formats and bilingual versions. FR and YDY are also popular but not as popular as YYeTs.

(3) How to become a member in YYeTs?

First write an e-mail to them with an application form telling them your interests and strengths. Then they will send you a ten-minutes dialogue to test your English. Normally, there is no problem if you get the meanings correct. After about one week, if you pass the trial translation, they will send documents and software to teach you how to do the subtitling with the subtitling software. YYeTs has its own subtitling software called "Timing Machine". Every translator is required to learn how to do the timing because the translator may not only be responsible for the translation. He/she may also do the timing and encoding.

(4) How do the fansub work to produce a subbed episode?

The process requires great teamwork and cooperation. First, the raw provider will get the source from the server and sent back to the FTP. Then the timer will spot the timing of the source and send the dialogue list with timing to the translator. Sometimes, the translator will also do the timing. When the translation is finished, it will go to proof-reading and editing. When everything is ready, the encoder will do the final combination.

(5) What strategies do fansubbers usually adopt?

Any strategies will be OK. The most important thing is that you get the meaning correct. Usually fansubbers like to use pop 
cultural expressions, web-language and add annotations to explain the terms, or add comments. We object the "academic" way by the mainstream subtiters and like to be more creative and idiosyncratic.

(6) How do fansubbers translate humor?

Humor is really difficult to translate because it concerns complex cultural signs. Usually, we will recreate the humor and add annotations to explain the culture difference. We do not only domesticate the humor without any explanation because we like our audience know what is really happening in the program.

(7) What do you think are the strength and weakness for fansubbing?

We join the team due to our love to the programs. We can understand the programs much better than the mainstream subtitler. We have a better interaction with the audience and the fansub credit with our nicknames on the screen provide us a good opportunity to communicate with their audience. Besides, the efficient work and creative translation are very attracting. But, of course, there will be some mistakes and errors with the translation because we are all amateurs. 